Vol 2. No 1. Februari 2018

ISSN 2580-5029

\title{
EFEKTIVITAS MIKRONUTRIEN ZINC DARI EKSTRAK LABU KUNING (Cucurbita Moschata D) TERHADAP PERILAKU KAWIN MENCIT (Mus Musculus) JANTAN
}

\author{
Linda Prasetyaning ${ }^{*}$, Risa Purnamasari ${ }^{2}$, Nova Lusiana 1 \\ 1. Fakultas Psikologi dan Kesehatan UIN Sunan Ampel,Surabaya, Indonesia \\ 2 Fakultas Sains dan Tekhnologi UIN Sunan Ampel, Surabaya, Indonesia \\ *Email: linda.prasetyaning@gmail.com
}

\begin{abstract}
Male reproductive ability ability has a linear correlation with libido and testosterone. Both are associated with various things main food consumption such as protein, vitamins and minerals. Aphrodisiac is an ingredient or drug that arouses sexual arousal or libido. Pumpkin is an example of food from plants with the highest content of zinc. This study was to determine whether there is a difference between the content of zinc on the peel, flesh and pumpkin seeds against sexual activity of mice. The experimental animals used were 24 male, group I mice as control group, Group II was grouped with pumpkin peel extract, Group III was grouped with extract of pumpkin flesh, Group IV was grouped with extract of pumpkin seeds. The dose used is $2 \mathrm{gr} / \mathrm{kg} \mathrm{BB}$ and volume of $0.2 \mathrm{ml}$ is given for 35 days. Sexual Activity is observed every day by the position of male mice riding females. Based on Anova One Way test results showed there are differences in sexual activity mice males in each group ( $\rho$ 0.000). The difference of the result of the number of mounts indicated that the giving of yellow pumpkin extract had an effect on the increase of mating behavior of male mice. The group treated with the extract of pumpkin flesh showed the highest number of mice mounts (mean $=24,1667$. Further research is needed to get a clearer picture of the composition of the pumpkin nutrients that indirectly affect fertility in men.
\end{abstract}

Keywords: pumpkins, sexual activity, mice mounts

\begin{abstract}
ABSTRAK
Kemampuan reproduksi pria memiliki korelasi linier dengan libido dan hormon testosteron. Keduanya berhubungan dengan berbagai hal utamanya konsumsi makanan seperti protein, vitamin dan mineral. Afrodisiak (aphrodisiac) adalah bahan atau obat yang membangkitkan gairah seksual atau libido. Labu kuning merupakan contoh makanan dari tumbuhan dengan kandungan zinc paling tinggi. Tujuan penelitian ini adalah untuk mengetahui ada tidaknya perbedaan antara kandungan zinc pada kulit, daging dan biji labu terhadap aktivitas seksual mencit. Hewan coba yang digunakan adalah 24 mencit jantan Kelompok I merupakan kelompok kontrol, Kelompok II merupakan kelompok yang diberi ekstrak kulit buah labu, Kelompok III merupakan kelompok yang diberi ekstrak daging buah labu, Kelompok IV merupakan kelompok yang diberi ekstrak biji buah labu. Dosis yang digunakan adalah $2 \mathrm{gr} / \mathrm{kg}$ BB dan volume $0,2 \mathrm{ml}$ diberikan selama 35 hari. Perilaku kawin diamati setiap hari ditandai dengan posisi mencit jantan menunggangi betinanya. Berdasarkan hasil uji Anova One Way menunjukan terdapat perbedaan perilaku kawin mencit (Mus musculus) jantan pada setiap kelompok $(\rho 0,000)$. Perbedaan hasil jumlah tunggangan mengindikasikan bahwa pemberian ekstrak daging buah
\end{abstract}


labu kuning berpengaruh terhadap peningkatan perilaku kawin mencit jantan, Kelompok yang diberi perlakuan ekstrak daging buah labu memperlihatkan jumlah tunggangan mencit yang paling tinggi (mean=24,1667). Diperlukan penelitian lebih lanjut untuk mendapatkan gambaran yang lebih jelas mengenai komposisi nutrisi labu kuning yang secara tidak langsung mempengaruhi kesuburan pada pria.

Kata Kunci: Labu Kuning, perilaku kawin, tunggangan

\section{PENDAHULUAN}

Pernikahan sejatinya merupakan wadah untuk menampung limpahan kasih sayang. Tempat mencurahkan cinta antar pria dan wanita sesuai tuntunan Al-Qur'an. Seperti dalam firman-Nya; "Dan diantara tanda-tanda kekuasaanNya ialah Dia menciptakan untukmu isteri-isteri dari jenismu sendiri, supaya kamu cenderung dan merasa tenteram kepadanya, dan dijadikanNya diantaramu rasa kasih dan sayang. Sesungguhnya pada yang demikian itu benar-benar terdapat tanda-tanda bagi kaum yang berpikir". (QS. Ar-Ruum: 21).

Ketidakharmonisan rumah tangga disebabkan oleh multifaktor. Salah satunya adalah disfungsi ereksi dan ejakulasi dini. Insidensi disfungsi ereksi meningkat sesuai dengan bertambahnya usia yaitu 12 kasus per 1.000 orang pada usia 40-49 tahun, 30 kasus per 1.000 orang pada usia 50-59 tahun, dan 46 kasus per 1.000 orang pada usia 6069 tahun (Schaeffer \& Bivalacqua, 2009). Pada penelitian di Amerika Serikat didapatkan insidensi disfungsi ereksi 5\% (Baldwin, 2011). Di Indonesia belum ada data pasti tentang insidensi disfungsi seksual, diduga kurang dari 10\% laki-laki yang menikah mengalami disfungsi ereksi (Info Kedokteran, 2011). Namun menurut data dalam kongres Urologi Asia IV di Singapura dinyatakan bahwa $14 \%$ dari pria berusia di atas 18 tahun yang menjalani rawat jalan di Asia ternyata menderita gangguan kemampuan ereksi, dan dari jumlah itu, yang terbanyak mengalami gangguan impotensi adalah pria perkotaan Cina $25 \%$, disusul pria-pria Indonesia $21 \%$ (urutan kedua). Dan berdasarkan penelitian yang pernah dimuat dalam Journal of the American Health Association, tiga dari 10 pria mengalami masalah seksual. Umumnya antara lain keluhan berupa ejakulasi dini $21 \%$, disfungsi ereksi $5 \%$, dan hasrat seksual yang rendah 5 \% (Dian N. Sulaeman, 2002). Proporsi kasus disfungsi ereksi dari keseluruhan kasus disfungsi seksual adalah 50\%. Prevalensi disfungsi ereksi pada pria berumur 40-50 tahun sebesar $40-50 \%$ dan meningkat seiring pertambahan umur. Disfungsi ereksi merupakan masalah yang kompleks dan multifaktor (Astutik, 2006).

Keharmonisan rumah tangga berkaitan erat dengan aktivitas seksual atau hubungan suami istri yang berkualitas dengan kuantitas yang memadai. Namun demikian dari paparan di atas ternyata data tentang kasus disfungsi ereksi (ejakulasi dini) banyak terjadi bukan hanya di Indonesia namun juga menjadi masalah global. 
Kemampuan ereksi memiliki korelasi linier dengan libido dan hormon testosteron. Keduanya berhubungan dengan berbagai hal utamanya konsumsi makanan seperti protein, vitamin dan mineral.

Dalam kajian biologi, terdapat istilah afrodisiak yaitu berbagai bentuk stimulant atau perangsang yang bisa membangkitkan libido atau nafsu seks. Afrodisiak sendiri bisa dikelompokkan menjadi dua. Pertama yang mempengaruhi secara fisik dan psikis misalnya melalui penglihatan, pengecapan, pembauan dan kesan seperti parfum. Kedua yang mempengaruhi dari dalam tubuh misalnya makanan, minuman, obat atau rempah-rempah. (Ismadi , 2003). Afrodisiak (aphrodisiac) adalah bahan atau obat yang membangkitkan gairah seksual atau libido (Dorland, 2002). Dari beberapa penelitian tumbuhan afrodisiak mengandung senyawasenyawa turunan saponin, alkaloid, tanin, dan senyawa-senyawa lain yang secara fisiologis dapat melancarkan sirkulasi atau peredaran darah pada sistem saraf pusat (serebral) atau sirkulasi darah tepi (perifer). Peningkatan sirkulasi darah ini akan memperbaiki aktivitas jaringan tubuh sehingga secara tidak langsung akan memperbaiki fungsi organ (Intisari Online, 2001). Beberapa jenis tanaman dengan kandungan Afrodisiak antara lain pasak bumi, kuncup bunga cengkeh, ginseng, rebung bambu tabah, kayu manis, lavender, cokelat dan labu kuning serta banyak lagi. Selain bahan Afrodisiak, beberapa mineral seperti zinc juga berperan dalam meningkatkan libido. Labu kuning merupakan contoh makanan dari tumbuhan dengan kandungan zinc paling tinggi. Sedangkan dari protein hewani, tiram adalah makanan yang tinggi kandungan zinc.

Penelitian ini akan berfokus pada labu kuning sebagai sumber afrodisiak dan zinc dikarenakan penelitian sejenis masih belum banyak dilakukan.

$$
\text { Penelitian El-Ghany }
$$

menunjukkan hasil yang positif antara pemberian zinc pada biji labu kuning dan peningkatan kemampuan seksual. Penelitian lain mengungkapkan bahwa pemberian ekstrak etanol biji labu kuning dosis 2,0 g/kg BB meningkatkan proses pemulihan morfologi dan motilitas spermatozoa (Hayati, 2012). Menurut Dr. Nalini Chilkov L.Ac., O.M.D, menyatakan kunci hubungan intim yang memuaskan adalah kelancaran sirkulasi darah pada tubuh. Darah harus terpompa merata ke seluruh bagian tubuh terutama alat vital. Sedangkan kekuatan seks terbesar manusia tetap terletak pada otak. Menurut Gold (2009) dalam bukunya Afrodisiacs mengemukakan bahwa labu kuning juga bisa menjadi obat bagi pria yang mengalami disfungsi ereksi atau impoten, serta meningkatkan gairah pada pria normal. Dalam penelitian tersebut, Gold mempelajari beberapa partisipan usia 18 hingga 64 tahun dengan menggunakan 40 macam aroma yang dapat meningkatkan gairah seksualnya. Hasilnya menunjukkan bahwa aroma pie labu kuning yang paling membuat pria bergairah. 
Biji labu sangat kaya akan seng atau zinc. Ini sangat berkhasiat terutama bagi pria yang mengalami pembesaran prostat. Selain itu, zinc juga sangat berguna untuk meningkatkan testosteron dan hasrat seksual. Biji labu memiliki kandungan zinc yang penting untuk mencegah berkurangnya hormon testoteron pada pria. Jenis biji-bijian satu ini sangat baik untuk meningkatkan libido. Karena menjadi sumber vitamin seperti vitamin $B, C, D, E, K$ dan mineral seperti kalium, niacin, kalsium, dan fosfor (Detik, 2011). Dari data di atas, penelitian terdahulu hanya mengukur kandungan labu kuning pada bagian biji dan daging. Sedangkan di bagian kulit belum pernah dilakukan penelitian untuk melihat kandungan zinc-nya. Oleh karenanya, dalam penelitian ini akan dikembangkan kepada komparasi efektifitas mikronutrien zinc pada kulit, daging dan biji Labu kuning (Cucurbita moschata $L$ ) terhadap perilaku kawin mencit (Mus Musculus) jantan.

\section{METODE (12 pt)}

Penelitian ini menggunakan jenis penelitian eksperimental laboratorium, merupakan pendekatan penelitian kuantitatif yang memenuhi semua persyaratan untuk menguji hubungan sebab akibat. Dalam penelitian ini pemberian ekstrak dari beberapa bagian buah labu kuning (Cucurbita moschata) diharapkan dapat berpengaruh terhadap peningkatan perilaku kawin 24 ekor mencit jantan. Penelitian di lakukan di
Laboratorium Terintegrasi UIN Sunan Ampel Surabaya

Pemberian ekstrak labu pada hewan coba dilakukan dengan cara sebagai berikut: mencit dikelompokkan menjadi empat kelompok. Kelompok I merupakan kelompok kontrol yang diberi aquades, Kelompok II merupakan kelompok yang diberi ekstrak kulit buah labu, Kelompok III merupkan kelompok yang diberi ekstrak daging buah labu, Kelompok IV merupakan kelompok yang diberi ekstrak biji buah labu. Pemberian larutan ekstrak secara per oral menggunakan jarum sonde dengan dosis $2 \mathrm{gr} / \mathrm{kg}$ BB dan volume $0,2 \mathrm{ml}$ diberikan selama 35 hari sesuai dengan waktu yang dibutuhkan dalam siklus spermatogenesis.

Perilaku kawin diamati setelah mencit jantan diberi ekstrak setiap hari kemudian di kawinkan dengan 3 ekor mencit betina selama 35 hari, perilaku kawin ditandai dengan posisi coitus mencit jantan yang berada di atas mencit betina, perilaku kawin dihitung berdasarkan intensitas posisi coitus mencit jantan menunggangi mencit betina.

Analisis data yang dilakukan adalah Anova One Way. Teknik analisa Anova One Way adalah prosedur pengujian hipotesis yang digunakan untuk mengevaluasi perbedaan mean dari 2 atau lebih treatment atau populasi

\section{HASIL DAN PEMBAHASAN}

Tahap pertama penelitian adalah pembuatan ekstrak daging, biji dan kulit buah 
labu tradisional yang ada di daerah Wonokromo, Surabaya, Jawa Timur. Kemudian dilakukan preparasi sampel yaitu dengan cara memisahkan kulit, daging dan bijinya. Kulit, daging dan biji di potongi menjadi lebih kecil karena untuk memudahkan dalam tahap pengeringan. Langkah selanjutnya yaitu menghilangkan kadar air dengan cara di oven dalam suhu $80^{\circ} \mathrm{C}$ selama 48 jam. Setelah kadar air benarbenar hilang pada kulit, daging dan biji dan menghasilkan simplisia. Kemudian simplisia dihaluskan dengan cara di blender hingga benar-benar halus.

Setelah dilakukan preparasi sample maka dilakukan maserasi. Langkah awal yang dilakukan adalah pemilihan larutan, dimana larutan yang digunakan dalam penelitian ini adalah metanol. Perbandingan yang dilakukan 1:2 untuk daging, 1:4 untuk kulit dan biji. Maserasi di lakukan selama 48. Setalah itu dilakukan penyaringan dan didapatkan residu dan filtrat. Residu yang ada diremaserasi selama 24 jam.

Setelah di dapatkan ekstrak maka di lakukan pembuatan larutan stok dengan konsentrasi 2gr/Kg BB mencit. Pembuatan dilakukan dengan penimbangan ekstrak sebanyak 0,08 gram dan diencerkan dalam 5 $\mathrm{ml}$ aquades. Setelah larutan stok di buat maka perlakuan pada mencit dilakukan. Perlakuan dilakukan dengan cara injeksi oral sebanyak 0,2 ml menggunakan jarum sonde selama 36 hari perlakuan. Selain perlakuan pemberian ekstrak kulit, daging dan biji, mencit juga di timbang setiap harinya.

Labu kuning memiliki kandungan senyawa alkaloid yang bermanfaat untuk memacu system saraf, menaikkan atau menurunkan tekanan darah dan melawan infeksi mikrobia. Labu kuning mengandung senyawa fenolik alam yang potensial sebagai antioksidan dan mempunyai bioaktivitas sebagai obat. Senyawa ini dapat ditemukan pada batang, daun, bunga dan buah. Flavonoid dalam tubuh manusia berfungsi sebagai antioksidan, melindungi struktur sel meningkatkan aktivitas vitamin $\mathrm{C}$ anti inflamasi dan antibiotic (Erfanur, 2014).

Labu kuning (cucurma morchata D) mengandung banyak vitamin dan mineral, zat gizi yang terkandung di dalam setiap $100 \mathrm{~g}$ labu kuning $34 \mathrm{kal}, 1.1$ protein 0.3 lemak 08 mineral, $45 \mathrm{mg}$ kalsium dan 0,3 mg zinc. Defisiensi zinc dapat menyebabkan gangguan pertumbuhan organ reproduksi, khususnya testis pada pria dan kematangan seksual, gangguan sekresi vesika seminalis dan prostat, gangguan sekresi vesika seminalis dan prostat. Gangguan fungsi sel leydig dapat menyebabkan turunnya produksi androgen, yang utamanya adalah testosteron. Gangguan kesuburan akibat kekurangan zinc dapat berupa rendahnya volume semen akibat turunnya sekresi vesika seminalis, gangguan kualitas sperma dan gangguan kuantitas sperma karena menurunnya sekesi testosterone yang berperan dalam proses 
spermatogenesis dan maturasi sperma di epididimis. (Eddyman, 2012)

Perilaku hewan adalah ekspresi untuk menyesuaikan diri dengan kondisi internal dan eksternal yang berbeda. Perilaku dapat digambarkan sebagai respon hewan terhadap stimulus. Pengamatan perilaku hewan dapat dilakukan di lapangan dan di laboratorium. Pengamatan perilaku hewan di lapang adalah melihat perilakunya yang muncul secara alami di alam sedangkan pengamatan perilaku hewan di laboratorium adalah melihat perilakunya yang muncul di kandang yang dibuat. Pengamatan perilaku tersebut berfungsi untuk membandingkan perilaku hewan yang muncul pada kondisi yang berbeda. Perilaku nokturnal adalah perilaku yang lebih aktif dilakukan oleh hewan pada malam hari. Mencit (mus musculus) merupakan hewan noktural, yang banyak melakukan aktivitas hidupnya di malam hari, termasuk juga melakukan aktifitas seksual yaitu kawin.

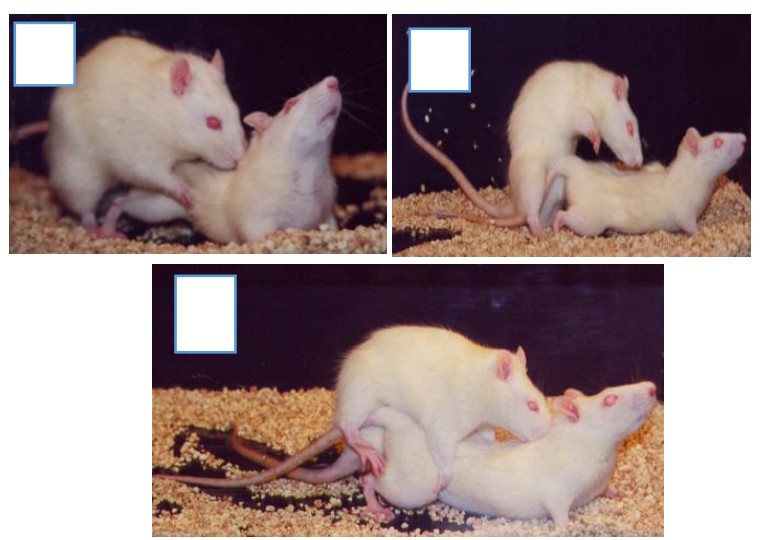

Gambar 1 Perilaku kawin mencit yang ditandai dengan banyaknya jumlah tunggangan perhari selama 35 hari (Dokumen Pribadi, 2017)

Perilaku kawin diamati setiap hari ditandai dengan posisi mencit jantan menunggangi betinanya, berdasarkan hasil penelitian jumlah tunggangan mencit yang paling tinggi adalah pada mencit yang diberi ekstrak daging labu kuning (mean=24,1667). Rata-rata hasil pengamatan perilaku kawin setiap kelompok dapat dilihat pada gambar 1.

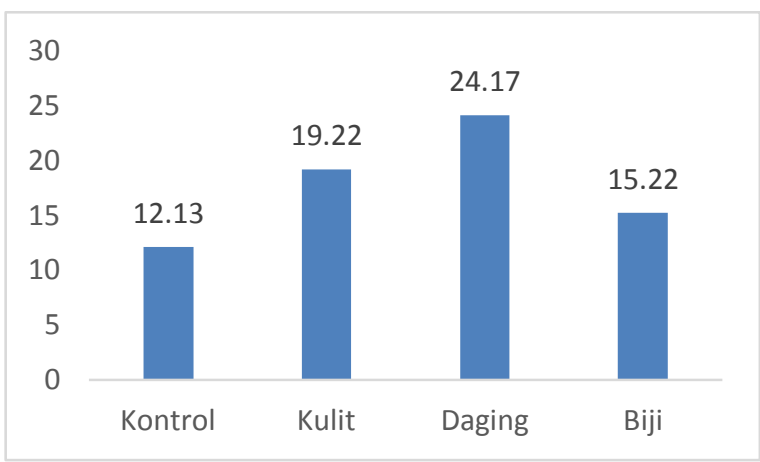

Gambar 2 Rata-rata Jumlah Tunggangan

Berdasarkan gambar 2 pada pengamatan perilaku kawin didapatkan hasil rata-rata tunggangan yang dilakukan oleh mencit jantan pada mencit betina tertinggi yaitu pada kelompok yang diberi perlakuan ekstrak buah labu. Yaitu sebanyak 24x Tunggangan/hari, sedangkan pada kelompok kontrol yaitu sebanyak 12x tunggangan/hari, kelompok yang diberi perlakuan ekstrak biji labu yaitu sebanyak 15x tunggangan/hari, dan kelompok yang diberi perlakuan ekstrak kulit labu yaitu sebanyak 19x tunggangan/hari. 
Kemudian dilakukan uji Kolmogorov smirnov diperoleh hasil data jumlah tunggangan mencit berdistribusi normal, hal ini dapat dilihat dari nilai signifikansi $\mathrm{p}$ value $(0,148)$ yang lebih dari $\alpha(0,05)$ dan uji Lavene didapatkan data tersebut homogen, hal ini hal ini dapat dilihat dari nilai signifikansi $p$ value $(0,470)$ yang lebih dari $\alpha$ $(0,05)$ artinya syarat penggunaan uji Anova One Way dapat dilakukan. Hasil pengujian Anova dapat dilihat pada tabel 1

Tabel 1. Hasil Uji ANOva Perilaku Kawin

\begin{tabular}{lrrrrr}
\hline & $\begin{array}{c}\text { Sum of } \\
\text { Squares }\end{array}$ & Df & $\begin{array}{c}\text { Mean } \\
\text { Square }\end{array}$ & F & Sig. \\
\hline $\begin{array}{l}\text { Between } \\
\text { Groups }\end{array}$ & 487.63 & 3 & 162.543 & 57.029 & 0.000 \\
$\begin{array}{l}\text { Within } \\
\text { Groups }\end{array}$ & 57.003 & 20 & 2.85 & & \\
\hline Total & 544.633 & 23 & & & \\
\hline
\end{tabular}

Berdasarkan hasil uji ANOVA dapat disimpulkan bahwa terdapat perbedaan jumlah tunggangan mencit antara kelompok kontrol, dan kelompok mencit yang diberi ekstrak daging, kulit dan biji. Hal ini hal ini dapat dilihat dari nilai signifikansi $\mathrm{p}$ value $(0,000)$ yang lebih dari $\alpha(0,05)$ artinya terdapat perbedaan dari 4 kelompok (kontrol, daging, kulit dan biji).

Hal tersebut dapat terjadi diduga karena adanya senyawa triterpenoid, flavonoid, dan saponin yang terkandung didalam ekstrak buah labu, sesuai dengan hasil uji kandungan fitokimia yang di lakukan, senyawa-senyawa tersebut diduga dapat memodulasi sistem hormonal tubuh untuk meningkatkan produksi hormon testosterone, dengan meningkatnya produksi hormone testorteron menyebabkan pematangan sel spermatogonium sehingga menjadi spermatozoa, dan juga dapat menyebabkan peningkatkan libido pada mencit jantan. Sedangkan pada ekstrak kulit dan biji labu hasil pengujian kandungan fitokimia yang dilakukan, didalamnya hanya terkandung flavonoid saja, meskipun perilaku kawin pada kelompok tersebut meningkat dibandingkan dengan kelompok kontrol. Namun pengaruhnya tidak signifikan dibandingkan dengan kelompok yang diberi perlakuan ekstrak buah labu.

\section{KESIMPULAN}

Berdasarkan hasil penelitian dan uji statistic dapat ditarik kesimpulan bahwa terdapat perbedaan perilaku kawin mencit (mus musculus) jantan antara kelompok kontrol, dan kelompok mencit yang diberi ekstrak daging, kulit dan biji ( $p$ value 0,000). Kelompok yang diberi perlakuan ekstrak daging buah labu memperlihatkan jumlah tunggangan mencit yang paling tinggi (mean=24,1667)

$$
\text { Untuk penelitian selanjutnya }
$$
diharapkan dapat memperoleh gambaran yang lebih jelas mengenai komposisi nutrisi labu kuning yang secara tidak langsung mempengaruhi kesuburan pada pria.

\section{DAFTAR PUSTAKA}

Asaba A, Tatsuya H, Kazutaka M, Takefumi K. 2014. Sexual attractiveness of male chemicals and vocalizations in mice. Frontiers in Neuroscience, 8 
Allen AEC, Cheryl LC, Alexis JW, Donald WP, Elena C. Agonistic behavior in males and females: effects of an estrogen receptor beta agonist in gonadectomized and gonadally intact mice. Psychoneuroendocrinology, 35(7): 1008-1022.

Azadeh Sedigh, Mehrdad Modaresi, Akbar Pirestani. 2016. The effects of zinc supplement on fertility in male mice. Journal of Chemical and Pharmaceutical Research, 2016, 8(1):6670.

Abd El Ghanny, Dalia, A Hafez et all.(2010) Biological Study on The Effect Of Pumpkin Seeds and Zinc on Reproduction Potential of Male Rats. $5^{\mathrm{TH}}$ Arab and $2^{\text {nd }}$ International Annual Scientific Conference.

Cunningham, J.G. 2002. Textbook of Veterinary Physiology. Ed ke-3. W.B. Saunders Company, Philadelphia. pp. 1 - 575.

Ellsworth P (2012). 100 tanya jawab mengenai Disfungsi Ereksi, Ed. 2 Jakarta; PT Indeks 2011.

Ganong WF, Buku ajar Fisiologi Kedokteran. Edisi ke-22 , Jakarta EGC.

Erfanur Adlani (2014) Penapisan Kandungan Fitokimia padda Buah Labu Kuning (Cucurbita Moschata) , jurnal Tekhnologi dan industry,Politekhnik Tanah Laut. vol 3 No. 1, juni 2014.

Eddyman W. Ferial. (2012) Gizi Infertilitas dan Penanganannya, FMIPA UNHAS Makassar.

Hess R, A., L,R de Franco, (2008). Spermatogenesis and Cycle of The Seminiferous Epithelium in Molecular Mechanism in Spermatogenesis, Edited by C. Y. Cheng. Landes Bioscience and Springer , London.

Mahkota, Annisyiah Wira. (2013). Uji Aktivitas Afrodisiaka Ekstrak Biji Makisa (Passiflora ligularis Juss) asal kabupaten Jeneponto terhadap mencit Jantan (Mus Musculus). universitas Hasanudin Makassar.

Nunn CL. 2002. Behavioural defences against sexually transmitted diseases in primates. Animal Behaviour, 66: 37-48.

Rosenfiel, A and M. A Fathalla. (1887). Reproductive physiology. The parthenon publishing group, New Jersey.
Setyadi, Aditya Dwi. (2006). Organ Reproduksi dan Kualitas Sperma Mencit (Mus Musculus) yang mendapat Pakan Tambahan Kemangi (Ocimum Basilicum) Segar. Skripsi. Fakultas Peternakan Institut Pertanian Bogor.

S. Aghaei, H. Nikzad, M. Taghizadeh (2013). Protective effect of Pumpkin seed extract on sperm characteristics, biochemical histology in adult male rats treated with Cyclophosphamide. Andrologia Journal Vol 46 Issue 8 pages 927-935.

Stopka P, Romana G. 2000. Conditional allogrooming in the herb-field mouse. Behavioural Ecology, 12 (5): 584-589.

Wijaya DI. 2012 . Efek Pemberian Suplemen Zinc yang Beredar di Indonesia Terhadap Motilitas dan Jumlah Spermatozoa Mencit Swiss Webster.

Wahba A, Hemaia M, Motave V, Abeer Y. Journal of bioscience, 1994; 1: 49-56.

Widowati, W., Sastiono, A., dan Rumampuk, R.J. 2008. Efek Toksik Logam. Penerbit Andi Yogyakarta, Yogyakarta. 309-325.

Yakubu MT, Akanji MA, Oladji AT. (2007) Male sexual Dysfunction and Methods Used in Assesing Medicinal Plants With Aphrodisiac Potential. Pharmacognosy Review Vol 1 (1).

Yamaguchi S, Miura C, Kikuchi K, Cellno FT, . Agusa T, Tanabe S. 2009. Zinc is an essential trace element for spermatogenesis. Proceedings of National Academy of Sciences. Juni 30; 106: p. 10859-10864. 